\title{
Depicting Absence: Thematic and Stylistic Paradoxes of Representation in Visual and Literary Imagery
}

\begin{abstract}
The article draws up an inventory of, and compares strategies for, the theoretical and critical treatment of the absence-presence interplay at stake in the literary and visual representations of absence. This brings to our attention a multiplicity of heterogeneous and, to a greater or lesser degree, marginal signifying phenomena that have in common patterns of disrupting and deviating from the standard conventions of creating and conveying meaning through figures of absence. Lacking a name for these disparate yet similar instances where meaning is created from empty signifiers, we have chosen to call them figural voids. This attempt to produce a critical inventory focuses on modern and contemporary approaches to the analysis of figures and figurations of absence in literature, visual arts, and cinema, relying on the works of Anne Cauquelin, Jean-Pierre Mourey, Philippe Le Roux, Maurice Frechuret, Bruno Duborgel, and Marc Vernet. Their theoretical positions stand in a variety of literary and artistic contexts that are seemingly disconnected yet can be brought together on the basis of their common affinity to figural voids. This calls for a comparative standpoint and can be illustrated with examples ranging across historical periods and disciplines: from Stoic writings to Alberto Moravia's Boredom, from Mallarmé's blank page to the controversial curatorial practices espoused by Yves Klein.
\end{abstract}

Keywords: absence, empty signifiers, figural voids, figures of absence, literary images, regimes of representation, visibility

Modern and contemporary landscapes of literary and artistic production bring to our attention a multiplicity of heterogeneous and, to a greater or lesser degree, marginal signifying phenomena that have in common patterns of disruption and deviation from the standard conventions of creating and conveying meaning. Our focus here falls on those instances where these semiotic effects are achieved through the deployment of (rhetorical) figures of absence, through the dynamic interplay of absence and presence in representations of absence as void, lack, nothingness, as blanks, as empty physical and conceptual spaces. Lacking a name for these disparate yet similar instances where meaning is created from empty signifiers, we have chosen to call them figural voids. The following pages are an attempt to provide a critical inventory of critical and theoretical approaches

2 Open Access. (C) 2021 Alexandra Irimia, published by De Gruyter. (c) BY-NC-ND This work is licensed under the Creative Commons Attribution-NonCommercial-NoDerivatives 4.0 International License. https://doi.org/10.1515/9783110642032-040 
to the analysis of figures and figurations of absence in literature and visual arts.

Under various paradigms and influences, from the interwar avant-gardes to the punk scene of the 1980s, from suprematist mysticism to quantum physics, from Zen Buddhism (differentiating between eighteen different kinds of void) to minimalist conceptual art, an impressive number of explorations of absence have seen the neon lights of the art scene, have drowned in typographic ink and oceans of monochrome, or have been projected, silenced, or performed in front of outraged audiences. As understood for our purposes, "figural void” refers equally to the white space on the museum wall where there is no picture, or to the white spaces inhabiting any text, any word, any graphic sign. Figural voids represent unused potentialities of figurability, regardless of medium and expected content. They are always engaging in play with (mostly unfulfilled) expectations.

Mallarmé's anxiety in front of the blank page does not stem from the material page itself, but from its being a figural void, a space of indeterminacy capable of hosting all potentialities while actualizing none. However, just like the typographic blanks separating - and even inhabiting - written words, the emptiness implied by the figural void is a prerequisite condition of representation. As Anne Cauquelin puts it in her study on the incorporeal as a critical category: "[Le vide] est présent avec et en même temps que toute parole prononcée, que toute énonciation quelle qu'elle soit, car il est la condition de cette énonciation même. [...] la condition est comprise dans ce qu'elle conditionne, comme étant son noyau et sa fin" (Cauquelin 2006, 30). The projection screen must be blank in order to properly accommodate any image. To put it briefly, the figural void is the figure of absence, whether manifest or implicit, that is inherent to and necessary for any representation, lying at its very core ${ }^{1}$ just like the paradoxical region of calm that remains untroubled in the eye of a tropical storm. Nothing spins in the vertiginous centre.

In this sense, any given figure is already a figure of absence. Differentiation against a background, just like the above-mentioned cleavage inflicted by the figural upon the image, from inside the image, is the mark of a split. It is the sign of an interruption, the opening of an internal abyss:

1 The idea is not new - it simply echoes in wider terms Maurice Merleau-Ponty's phenomenological insights, according to which visibility involves, implies, and is built upon invisibility: "Quand je dis donc que tout visible est invisible, que la perception est imperception, que la conscience a un punctum caecum, que voir c'est toujours voir plus qu'on ne voit, - il ne faut pas le comprendre dans le sens d'une contradiction - Il ne faut pas se figurer que j'ajoute au visible parfaitement défini comme en Soi un non-visible (qui ne serait qu'absence objective) (c'est-à-dire présence objective ailleurs, dans un ailleurs en soi) - Il faut comprendre que c'est la visibilité même qui comporte une non-visibilité" (Merleau-Ponty 1964, 295; emphasis in original). 


\begin{abstract}
Si l'on s'imagine un milieu absolument quelconque, sans la moindre différenciation interne, qu'il s'agisse d'un son, le plus uniforme et le plus continu qu'il se puisse, ou d'une surface indéfinie, unie, non-orientée, on aperçoit une première possibilité de structuration de ce milieu dans la simple solution de continuité. Un son rompu puis continué se mue en rythme. Ainsi, une articulation élémentaire du matériau précédemment amorphe est déjà une figure de l'absence, en ceci que c'est l'absence même, l'interruption ou le retrait du matériau, qui, dans l'instant de silence, crée la forme. La suppression ou la suspension de ce qui figure est déjà, intrinsèquement, une figuration de l'absence. La figuration montre ainsi qu'elle ne peut être, au gré des vents, soit figuration de la présence, soit figuration de l'absence, mais figuration de l'absence, par l'absence. (Le Roux 1987, 97)
\end{abstract}

The study of figured absence already has a certain (eclectic) tradition and several critical landmarks, especially in French theory. Jean-Pierre Mourey's edited volume of interdisciplinary essays points to the transmedial complexity of this particular category of figuration (Mourey 1987). Only one year later, Marc Vernet published Figures de l'absence: De l'invisible au cinema (1988), where he identifies five distinct figures used in cinematography - a spectral medium itself - to signal the existence of absent images that inhabit an off-screen space: looking at the camera, the subjective camera, superimposition, the portrait, and the absent character. More recently, Anne Cauquelin (2006) has revisited contemporary art through the lens of the four categories of the incorporeal (time, place, void, the expressible) as they are described in Stoic writings.

All these accounts testify to the complex and ambiguous nature of absence a feature that disqualifies it from the inventory of rigorous concepts. In his essay "Ombres, éclats, fragments," Jean-Pierre Mourey points to the three distinct meanings of the prefix $a b$ - in Latin. Firstly, $a b$ - "off, away" may be read as a sign of distancing; a purely spatial form of absence. Secondly, it may signify a lack, a more radical figure of loss, an ellipsis that interrupts a continuum. Thirdly, it is the mark of a deep, unbridged gap between two elements which it is impossible to reconcile with one another. The strongest example of this incompatibility would be the fact that any regime is prevented from properly accommodating the divine. ${ }^{2}$ One might think here of Hegel's account of the entry of Pompey the Great into the Holy of Holies in the Temple of Jerusalem, where the Emperor was amazed to discover that this most sacred room, which he imagined filled with sights unseen, was in fact empty (Baum 2009, 425). However, the realm of absence is so vast that it accommodates both that which cannot be figured and that which can only be

2 "L’incompatibilité suppose une différence radicale qu'aucun seuil [...] ne peut résoudre, effacer, suturer. [...] Aucun élément du monde sensible, aucune image ne peuvent donner une représentation adéquate du Divin. Cette représentation sera aimantée, travaillée par de l'irreprésentable" (Mourey 1987, 26). 
figured. ${ }^{3}$ As such, absence is a non-lieu, the paradoxical territory which lies at once outside of figuration and within it.

Further attempts at approaching absence will only reveal more of its inherent contradictions. For example, the figuration of absence meets its most radical form either in the absolute absence of figuration, or in its overabundance. Referring to multiple aesthetics built around horror vacui (baroque or Islamic art, to give only two common examples), Mourey points out that the awareness of an absence does not necessarily lead to silence, void, nothingness - and, broadly speaking, to what we have called a figural void. It can just as well trigger an infinite proliferation of figures, a swirl of numbing appearances, a staged yet unstable excess of figuration. ${ }^{4}$ Perhaps due to these extreme, polarized tendencies, the strongest effects of absence are those created through a certain staging, a careful mise en scène. In his article "La tabula rasa ou le vide de la peinture," Maurice Frechuret also validates this view, writing that "des mises en scène où les figures de l'absence se mettent en place, jamais frontalement, [...] mais dans des images progressives et elliptiques où les effets suggestifs sont souvent plus convaincants que la visibilité pure" (1987, 111). Let us give just one example: Yves Klein's empty exhibition, La Spécialisation de la sensibilité à l'état de matière première en sensibilité picturale stabilisée, opened in Paris in 1958 at the Iris Clert Gallery. It was by no means a careless enterprise, even if it consisted of nothing but a white, empty room. The walls had been painted by the artist himself; witty invitations had been sent; blue cocktails had been served at a blue entrance. The immaterial works "on display" (bits of Klein's pictorial sensibility, as he insisted on calling them) were sold for gold or simply taken away, impregnated in the clothes of visitors who had to pay as much as 1,500 francs to "see" them. "Ils sont tous aveugles!" Klein $(2006,22)$ said in disdain about those who complained about having nothing to see at his completely empty fully exhibit. But there was more than just

3 "La figuration s'instaure toujours, d'ores et déjà, sur fond d'absence: absence du réel qui est figuré” (Mourey 1987, 9).

4 “La conscience du manque (manque d'une vérité salvatrice, d'un socle, d'un fondement) n'entraîne pas pour autant le silence, le vide. Elle peut susciter un tourbillonnement de figures, des redoublements vertigineux: la prolifération des arabesques, la spirale des volutes, l'enfilade des masques cachent le vide, le rien. La scénographie de l'excès, la théâtralisation de la mise en abîme, les métamorphoses et les ambivalences déploient leur faste. Dans son Anthologie de la poésie baroque française, Jean Rousset note cette proximité: de la conscience du vide naît le besoin de l'illusion, de l'inconstance des choses, le goût du décor, du déguisement. [...] Ainsi, quand l'expérience intérieure est l'intuition de l'inconstance, du peu de poids des choses, d'une vacuité, l'une des attitudes éthiques, esthétiques est de jouer de l'illusion, de redoubler celle-ci. Une autre stratégie serait le dénuement, le silence, l'effacement de soi.” (Mourey 1987, 7) 
nothing to see, for the matter of nothingness is more complex than that; in Gaston Bachelard's words: “There is an imaginary beyond, a pure beyond, one without a within. First there is nothing, then there is a deep nothing, then there is a blue depth" (Bachelard 1988 [1943], 167-168).

The figurations of absence are, therefore, endowed with a rhetoric and a topology of their own. Nevertheless, the resulting regime of figuration is not to be mistaken for a regime of representation: the difference between the two is that, while figuration refers to the articulation of figures, representation implies a more or less transparent strategy of mimesis, a certain repetition and reproducibility (Mourey 1987, 11). Mourey continues his argument by explaining how the fragment (in fact, any result of an interruption, a syncope, an ellipsis) is a matrix for figuring absence, for it is the trace of a loss, the present mark of an absence, and it functions by the logic of synecdoche. Other figures able to embody an absence may take on a different logic - the logic of metaphor, for example. ${ }^{5}$

Afterwards, the French critic points to another necessary distinction between the "presentification" of absence (the return of the absent as present, the overcoming of the $a b$-) and the figuration of the absent as absent (Mourey 1987, 32). According to him, the work of figuring absence - articulating figures that signify absence and render it perceptible - is a work of staging, a way of keeping it at a distance through subtle effects that replace, with a stronger impact, the usual inventory of signs explicitly gravitating around the idea of absence (deserted or abandoned places, graves, ruins). ${ }^{6}$ Mourey's hypothesis is based on examples drawn from Romantic or modern painting (Caspar David Friedrich, de Chirico), but its relevance is broader and exceeds the margins of the canvas. One can recognize it in the words of Maurice Blanchot, who refers to the same effect of neces-

5 “C’est un fragment, il porte la trace de la violence des hommes et du temps: ses bords sont à vif et le vif de cette coupure le marque comme fragment. Parmi les figures de l'absence, les unes sont des restes du corps, de l'objet perdu [...]. Les autres sont produites en substitution à ce qui a été perdu. [...] Métaphores de l'absent, elles peuvent aussi par l'unité, l'euphorie de leur forme, affirmer la pérennité de ce qui a disparu. La puissance du fragment tient à sa nature paradoxale. Ce qui saute aux yeux, c'est ce qui manque, fait défaut” (Mourey 1987, 42-43).

6 “Tout autrement, certaines peintures mettent en scène l'absence. Elles produisent (pro-ducere) un effet d'éloignement, de défection ou de manque. Celui-ci ne résulte pas d'une figure, d'un détail nommables, localisables. L'impression d'absence naît d'un je ne sais quoi qui est l'effet de l'ensemble du dispositif pictural, d'une scénographie. La peinture de De Chirico, de Friedrich serait fastidieuse si elle se réduisait à un catalogue de signes de l'absence: places vides, fenêtres fermées, roulottes abandonnées pour le premier, ruines, tombeaux, bateaux échoués, arbres morts pour le second. La désolation et le vertige du vide, chez Friedrich, naissent du télescopage d'un plan proche (avec ou sans personnage) et d'un plan lointain. Les plans intermédiaires sont supprimés" (Mourey 1987, 33). 
sary distancing when exploring the poetic possibilities of grasping absence: "We see clearly, then, why poetic language can revive things and, translating them in space, make them apparent through their distancing and their emptiness: it is because this distance lives in them, this emptiness is already in them; thus it is right to grasp them, and thus it is the calling of words to extract the invisible center of their actual meaning” (Blanchot 2003 [1959], 58). Or, several paragraphs earlier, he speaks of

that ability to represent by absence, and to manifest by distance, which is at the center of art, an ability that seems to distance things in order to say them, to keep them apart so that they can be illumined, a capability of transformation, translation, in which it is this very apartness (space) that transforms and translates, that makes invisible things visible and visible things transparent, thus makes itself visible in them and is revealed as the luminous heart of invisibility and unreality from which everything comes, and where everything is completed. (Blanchot 2003 [1959], 56)

Maurice Blanchot situates the figurations of absence at the crossroads of language and the realm of visibility. In a similar gesture, Mourey acknowledges that this ontologically unstable concept is, quite transparently, as much a matter of writing as it is one of seeing. ${ }^{7}$ Moreover, he adds that the figuration of absence not only transcends the limits of a single medium but even goes beyond the linguistic and the visual. Towards the end of this article, we shall explore in more detail how semantic vacuums are figured.

It is precisely because absence can take many forms that eventually it gives up all form. However, its presence can still be figured, for we have already shown that the figure is not a form but rather an event, just as figuration is not a representation, an indication, a signification, or an image, as described by Husserl (1969, 27-35). In this sense, Bruno Duborgel identifies a specific figure of absence in moiré patterns, a strange articulation of space which allows for an endless interplay of appearance and disappearance. What is visible can be seen because of the invisibility of a complementary figure; due to the permanent codependency

7 "La figuration de l'absence dans du visible, sa visualisation, ne sont pas une opération simple dès lors, mais un redoublement entre le dire et le voir. Ce qui se donne à voir dans une peinture a certes son propre ordre spatial, architectonique, mais en même temps, comme telle ou telle description littéraire, ce qui s’y figure est d'ores et déjà du discours (un certain discours sur le sujet humain, sur l'être du monde). [...] L'étude des figurations de l'absence permet de repérer des points nodaux, éléments communs au discours philosophique et à l'image littéraire, picturale. [...] les éléments qui s'imposent comme déterminants dans les figurations de l'absence appartiennent à la fois à l'ordre du discours et du voir. Dans la dialectique de la présence et de l'absence, ils s'altèrent, s'inversent, se métamorphosent” (Mourey 1987, 41-42). 
of absence and presence, the image is unstable and momentary, emerging from the potentialities of the interwoven inscription and effacement in the pattern of a texture (or a text):

moiré - [...] étoffe devenue sub-stance de l'apparition et de la disparition, espace des reconversions souples et incessantes du même et de l'autre. Chaque présence d'une configuration de formes et de rythmiques lumineuses se nourrit d'une disparition, "absorbe" un état précédent, mais aussi bien ne fait que tenir en suspens son retour possible. Le disparaître n'est guère que s'absenter; l'apparaître fait corps avec l'absence dont il se soutient; il n'est lui-même qu'une des figures momentanées, dé-couverte, des émergences possibles du tissu ou texte. Chaque état de présence portée à la visibilité retient - au double sens simultané de “tenir en retrait” et de "se souvenir" - l'altérité et l'absence que sa propre mise en exergue semble mettre entre parenthèses, le temps d'une posture du regard. [...] L'inscription et l'effacement se disent l'un l'autre [...] et se donnent paradoxalement coefficients de profondeur sur surfaces mobiles. (Duborgel 1987, 69)

In “Ceci est mon corps," Philippe Le Roux formulates two challenging questions. The first one is closely related to the features of moire patterns: if absence can only be understood in relation to presence, would it not be worth asking whether the presence and the absence are each the negation of the other, or whether, on the contrary, they imply each other in the act of figuration? Le Roux's answer is that the very figuration of absence is, simultaneously, fundamental to and threatening for this frequently misunderstood opposition. The figured absence, he says, already takes the consistency of a presence, despite the fact that it engenders a double absence: the absence which is figured, as well as the absence inherent in every figuration. The second question draws on an analogy: if figuration engenders some sort of presence, what is it that opposes figuration in the same way as absence opposes presence? To this, Le Roux replies:

L’ipséité, sans autre forme qu'elle-même, demeure inarticulée, et n’est ni énoncée ni montrée; elle est, à la limite, inaccessible, et, plus spécialement, invisible, et s'apparente davantage à l'absence qu'à la présence. A l'inverse, la figuration met le visible en formes, l'interprète, le manifeste, et, par là, y prépare l'initiative du spectateur par laquelle advient la présence. Toute figuration, fût-elle d'absence, est aussi, comme figuration, une présence. La figuration surmonte ainsi l'équivoque de l'absence et de la présence, laissant en arrière l'ipséité du réel innomé. (Le Roux 1987, 107)

A slightly different vocabulary further complicating the relations between absence and presence is used by Anne Cauquelin when she revisits, from the perspective of contemporary art, the figuration of the void as conceived by the Stoics. According to Apollodorus, quoted by Diogenes Laertius, to pan, "the All”, includes to holon, "the finite body of the world," and the void, an infinite space 
deprived of direction, limits, orientation, or content. "By the totality of things, the All, is meant, according to Apollodorus, (1) the world, and in another sense (2) the system composed of the world and the void outside it. The world then is finite, the void infinite" (Laertius 1925, 247). This void surrounds the world (it is nowhere to be found inside it) and counts as one of the four species of the "incorporeal," together with time, space, and the expressible. Moreover, the only determination that applies to it is the ability to contain matter without actually doing so. Diogenes states the same about all incorporeals:

The world, they say, is one and finite, having a spherical shape, such a shape being the most suitable for motion [...]. Outside of the world is diffused the infinite void, which is incorporeal. By incorporeal is meant that which, though capable of being occupied by body, is not so occupied. The world has no empty space within it, but forms one united whole. This is a necessary result of the sympathy and tension which binds together things in heaven and earth. (Laertius 1925, 245)

For the Stoics, the void was impossible to figure. Its role is precisely to make room for figuration, to create a space for the world to breathe, inserting a neutral space (Cauquelin 2006, 36) that allows for the play and movement of signs. Three examples of figural voids (formes $d u$ vide, as Cauquelin calls them) are given, partly overlapping with the figures of absence identified by Jean-Pierre Mourey. The first form of the void is the gap, the pit, the hole (le trou), which appears in a pre-existing dispositif as an interruption or a lack; either way, its ontological regime is a negative one. The second form described by Cauquelin is "l'immatériel sous le signe du blanc," exemplified by monochrome paintings. Just like the first form of the void, the monochrome requires the materiality of a medium in order to make itself seen. The empty canvas, as a negation of painting, needs to be put on display "somewhere" in order to affirm itself. A scene from Alberto Moravia's novel La Noia [Boredom] is an excellent example of performative ekphrasis that proves how an empty canvas becomes a work without becoming less empty:

I remember perfectly well how it was that I stopped painting. One evening, after I had been in my studio for eight hours, painting for five or ten minutes at a time and then throwing myself down on the divan and lying there flat, staring up at the ceiling for an hour or two all of a sudden, as though at last after so many feeble attempts I had had a genuine inspiration, I [...] slashed repeatedly at the canvas on which I had been painting, not content until I had reduced it to ribbons. Then from a corner of the room I took a blank canvas of the same size, threw away the torn canvas and placed the new one on the easel.

Immediately afterward, however, I realized that the whole of my - shall I say creative? energy had been vented completely in my furious and fundamentally rational gesture of destruction. I had been working on that canvas for the last two months, doggedly and without pause; slashing it to ribbons with a knife was equivalent, fundamentally, to finishing it - in a negative manner, perhaps, as regards external results. In fact my destruction of 
the canvas meant that I had reached the conclusion of a long discourse which I had been holding with myself for an interminable time. It meant that I had now planted my foot on solid ground. And so the empty canvas that now stood on the easel was not just an ordinary canvas which had not yet been used; it was a particular canvas that I had placed on the easel at the termination of a long job of work. (Moravia 2004 [1960], 3-4)

Last but not least, the third form of absence identified by Anne Cauquelin is withdrawal or displacement - "le retrait ou le déplacement." This refers to multiple phenomena that push the contemporary work of art towards its periphery and its context, abandoning its pretensions of producing specific objects defined by their inner consistency (Cauquelin 2006, 79-80). Yves Klein's 1962 empty exhibition of a room from which he had removed all paintings, or Robert Morris's Statement of Aesthetic Withdrawal (1963) are works that dislocate the scope of artistic practice from the realm of visibility and insert it into a conceptual space. Morris's work consists of a typed and notarized text serving to negate the "aesthetic quality and content" of a previous work by the same artist, referred to as "Exhibit A." In other words, the second work is nothing more than the statement of a loss, a deprivation: the voluntary withdrawal of aesthetic value from another work. In a sense, the gesture reiterates in conceptual terms the visual erasure of a Willem de Kooning drawing by Robert Rauschenberg (which had taken place exactly ten years earlier), with the difference that the author of the original work is now identical with the author that engenders and signs its disappearance. Towards the end, Anne Cauquelin's analysis performs a similar gesture of self-erasure. Her extensive attempt at illustrating, describing, and defining the incorporeal concludes with recognition of the overwhelming indeterminacy of the subject matter that immediately renders any such attempt vain, null and void. ${ }^{8}$

The figures of absence already identified by the French theorists cited above are not mutually exclusive. With the exception of Vernet's five figures pointing to the absent presence of an off-screen space in cinematography, these figural voids are not medium-specific either. Rather, one could consider them attempts to grasp absence from fleeting viewpoints and always-too-narrow angles. With the full awareness that aiming to create an exhaustive taxonomy of such figures is nothing short of a utopian endeavour, we have drawn here a comparative chart of contemporary theoretical approaches to figural voids in literature and visual arts. Simultaneously, as an instrument for further investigations, our enquiry reveals

8 "Inutile de les illustrer [les incorporels], ils n'ont pas d'image; inutile de les décrire, ils n'ont pas de forme - et en cela, ils sont bien invisibles; inutile de les assigner à résidence, ils n’ont rien qui puisse les fixer" (Cauquelin 2006, 133). 
how the many relationships between the written word and the artistic image can be explored not only in the positive mode of presence, but also in the negative ontological regime of absence.

\section{Works cited}

Bachelard, Gaston. "The Blue Sky." Air and Dreams: An Essay on the Imagination of Movement. By Bachelard. 1943. Trans. E. R. Farrell and C. F. Farrell. Dallas: The Dallas Institute of Humanities and Culture, 1988. 161-174.

Baum, Devorah. "Le Rien et les Juifs." Vides: Une retrospective. Eds. John Armleder, Mathieu Copeland, Gustav Metzger, Mai-Thu Perret, and Clive Phillpot. Paris: Centre Georges Pompidou; Berne: Kunsthalle Bern, 2009. 425-431.

Blanchot, Maurice. The Book to Come. 1959. Trans. Charlotte Mandell. Stanford: Stanford University Press, 2003.

Cauquelin, Anne. Fréquenter les incorporels: Contribution à une théorie de l'art contemporain. Paris: PUF, 2006.

Duborgel, Bruno. "Moires intérieures: Sur quelques tapis photographiques de Maurice Muller." Figurations de l'absence: Recherches esthétiques. Ed. Jean-Pierre Mourey. Saint-Étienne: Centre interdisciplinaire d'études et de recherches sur l'expression contemporaine (CIEREC), 1987. Travaux-Université de Saint-Étienne 60. 69-94.

Frechuret, Maurice. "La tabula rasa ou le vide de la peinture." Figurations de l'absence: Recherches esthétiques. Ed. Jean-Pierre Mourey. Saint-Étienne: Centre interdisciplinaire d'études et de recherches sur l'expression contemporaine (CIEREC), 1987. TravauxUniversité de Saint-Étienne 60.111-126.

Husserl, Edmund. "Expression et signification.” Recherches logiques: Prolégomènes à la logique pure. By Husserl. Trans. Hubert Élie, Lothar Kelkel, and René Schérer. Vol. 2. Paris: PUF, 1969. 27-35.

Klein, Yves. Vers l'immatériel. Paris: Éditions Dilecta, 2006.

Laertius, Diogenes. The Lives and Opinions of Eminent Philosophers. Trans. Robert Drew Hicks. Vol. 2. London: Heinemann, 1925.

Le Roux, Philippe. “Ceci est mon corps.” Figurations de l'absence: Recherches esthétiques.

Ed. Jean-Pierre Mourey. Saint-Étienne: Centre interdisciplinaire d'études et de recherches sur l'expression contemporaine (CIEREC), 1987. Travaux-Université de Saint-Étienne 60. 95-110.

Merleau-Ponty, Maurice. Le Visible et l'invisible. Paris: Gallimard, 1964.

Moravia, Alberto. Boredom. 1960. Trans. Angus Davidson. New York: New York Review Books, 2004.

Morris, Robert. Document. 1963. Museum of Modern Art, New York. Object no. 516.1970. https://www.moma.org/collection/works/79897 (19 December 2018).

Mourey, Jean-Pierre. “Ombres, éclats et fragments." Figurations de l'absence: Recherches esthétiques. Ed. Mourey. Saint-Étienne: Centre interdisciplinaire d'études et de recherches sur l'expression contemporaine (CIEREC), 1987. Travaux-Université de Saint-Étienne 60. 25-48.

Vernet, Marc. Figures de l'absence: De l'invisible au cinéma. Paris: Éditions de l’Étoile, 1988. 


\begin{abstract}
Alexandra Irimia is a $\mathrm{PhD}$ candidate in Comparative Literature at Western University in London, Ontario. Having a background in literary studies and political science, she is currently conducting research on text-image relations, bureaucratic poetics, and figures of absence in literature and visual arts. Her work combines translation projects with teaching and research assistantships in world literature, film studies, and image studies.
\end{abstract}


